the nucleic acid core for genetic information. In some cases now, these two have been separated. The specific antigon for poliovirus, antigen $D$, has been identified but not yet isolated; its poteney, however, can bo measured accurately by gol-diffusion assay, by which means a unit of potency has been established. This procedure makes it possible to introduce precise controls in the culture of tho virus and in tho proparation of inactivated vaccine. It can also be used in the case of other virus diseases.

The remaining paper describes tho romarkablo progress which has boen made in tho use of fluorescont dyes in serological tests. The dyed molecules of antibody are deposited wherever an appropriate antigen is prosent. The spparatus requirod is very simple, consisting of an ordinary microscope illuminated with long-wave ultraviolet light, which is cut off by a filter at tho eyepinco so that only tho fluorescent rays pass through to the observer. The technique is quick and inoxpensive.

It can be used for the immunological staining of bacteria, such as Group $A$ stroptococci in a mixed flora, or the onteropathogenic cells of $E$. coli, which are todious to diagnose by other methods. P'ossibilities for its use in research are attractive. It has alroady served in the identification of plasma cells as tho original souree of antibody, and confirmed that in rheumatoid arthritis the patient is making an auto-immune reaction against antigens in the affected joint. By the sams procedures the formation of insulin has been traced to the $\beta$-colls of tho pancrontic islets, and that of growth hormone to the acidophil cells of the pituitary. These are preliminary indications of many other discoveries still to come.

R. Weatherall

\title{
PENNSYLVANIAN PALAOECOLOGY
}

\begin{abstract}
A L'IHOUGH palwoecology is at prosent ono of the most A fashionable of all geological topics, it remains a field in which broad conclusions are often based on alarmingly meagre data: a fiold in which there is a growing literature on 'principles' but a dearth of detailed analysis. Zangerl and Richardson's recent study, "The Paleo. ecological History of Two Pennsylvanian Black Shales" *, is a model of what may be achieved by an intensive study of a limited vortical stratigraphic sequence. They have carried out an exhaustive analysis of the physical and biological uspects of two thin beds of Pennsylvanian (Des Moines) carbonaceous shale lying between the Volpen and the Minshall limestones in west-central Indiana. Although dotailed analysis is confined chiefly to three localities, the stratigraphy of othor comparable exposures has been described along a 30 -mile outcrop belt. Two of the quarries openod, Mecea and Logan Quarries, represent the initial stages of a marine transgression, whereas the shale at a third site, the Garrard Quarry, proved to bo of froshwater
\end{abstract} origin.

The flat-lying shale, which has a total thickness of $1 \mathrm{ft}$. 10.25 in. at the Mecca locality, was quarried over an area of $12 \times 15 \mathrm{ft}$., and removed to the laboratory, where a detailed fossil census was made for overy $\frac{1}{4}$ in. layer. This included the identification and charting of some 68,000 items, and occupied three operators for a period of two years. Tho accuracy of tho crnsus was established by comparing $X$-ray radiographs of the shale, in which the fossil content was cloarly shown.

The fauna of the marine shales includes olasmobranchs, palæoniscids, acanthodians, 'placoderms' and a varinty of sponges, coolenterates, bryozoans, brachiopods, gastropods, cephalopods, pelecypods, worms, arthropods, crinoids and conodonts, the systematic study of which will form tho basis of later publications. The present fossil analysis is concerned chiofly with proservation, articulation and relative distribution. There are marked difforences in rolative abundanes botwoen the various localities. Tho richness of the Mecca and Logan fish faunules is a local feature and is attributed, not to mass mortality, but to residual ponding. Individuals that diod from the effects of predation are abundant, the great majority of fish showing varying degrees of mutilation including bito wounds, mouthing and fonding. It is argued that the high concentration of sulphides and the lack of fragmenta. tion of vertebrates in the Garrard 'humulito' faunes indicate toxic bottom conditions as the local causes of

* Chicago Natural History Museum, Fieldiana: Geology Memoirs. 4: The Paleoecological History of 'Two Pennsylvanian 13lack Shales. By Rainer Zangerl and Eugene S. Richardson, jun. With contributions by Bertram Pp. xil +352 (56 plates). (Chicago: Chicago Natural History Muscum, 1063.) 10 dollars. mortality. The lattor fauna is quito distinct from that of the Mecca and Logan Quarries and contains a pleuracanth shark. Differences in preservation of pelecypods also suggest that some, for example, Myalina, diod chiefly from predation, and others, for example, Dunbarella, by poisoning. Detailed studies of coprolites, stomach ejects and gastric rosiduos aro included and it is concludod that sharks were the chief predators.

The authors suggest a correlation between the petrographic composition of the shales and the density of fossil content. Fossils are least common in the more carbonaceous shales, and it is suggested that the high content of decomposod plant products originated from a floating plant cover (flotant) overlying a varying, but always shallow, body of water, in which both bottom disturbanco and turbulont water woro raro, and in which the flotant, nearly in contact with the bottom, tended to oxclude fish. Faunal abundance is also related to colour of the shale and a profile of relative blacknoss of the shale was constructed, tho measurements boing mado by a 'Densichron' sensitive light meter. Chemical, spectrographic and clay mineral analyses and the petrographic descriptions of selected shale samples are also included, as is a detailed petrographic and palynologic study of the associatod undorlying Coal III $A$, which is used to establish a local palæogeographic history.

An analysis by R. I. Miller of the orientation of individual fossil fragmonts and thoir genoral dispersion is usod to suggest the presence and direction of a moderate current at one lovel, but only very slight or variable cur. rents (if any) at othor lovols.

The authors have supplemented their fossil obsorvations by a study of sedimentation and of decomposition rates of fish and plants in bayous and lagoons along tho Louisiann coast. These observations are used to suggest that the 12-in. profile of Mecca Quarry shale was deposited in about four yoars, the figure boing dorived chiefly from comparison of the present rate of aerobic decomposition of fish careasses and the thiokness of shele overlying the fossils. Docomposition of the soft parts of $a, 12-0 z$. fish and complete disarticulation of the skeleton occupied loss than a wook in a variety of oxisting Gulf Coast environments. Differences in tho preservation of coprolites in tho marino shety shales and the non-marine humulito deposits aro held to rosult from aerobic and annorobic decomposition respectively. In tho former, the upper surfaces of coprolites are flattened and irregular, but the lower are moro roundod. Sulphides are concentrated near the margins of the bodies and in the adjacent shale, suggosting that decomposition gases (chiefly hydrogen sulphide) worn not vented to the surface. This is held to indicate that tho micro-environment of the lower surface was anaerobic, 
while that of the upper surface was aerobic, becoming anaerobic only after burial by a thin layer of sediment. In the highly pyritic humulites, coprolites are not flattened and sulphides are confined to the fæcal mass. This results in smaller loss in volume, and suggests continuous aerobic decomposition.

Detailed investigations of vertical sections cut through fossil gastric residues, in which the escape effects of a gas bubble are clearly visible, are used to show that a mud cover, equivalent to 1-2 mm of shale, was deposited on fossil specimens from the time of their initial 'deposition' to the end of aerobic gas release in the carcasses. It is suggested that the cyclic character of the shale may be best interpreted by supposing that each pair of 'grey and black levols' represents an annual deposit, the low- and high-water alternations representing dry and wet seasons and thus suggesting sub-tropical climatic conditions.

Microstructural studies of the shales and their fossil content suggest that the muds wore nearly compacted at the time of deposition and, in contrast to other less carbonaceous marine muds, that they suffered little subsequent compaction under loading.

Analysis of the fossil content suggests the occurrence of three burial communities in the Mecca Quarry. The oldest is a well-preserved productid brachiopod, 'shelly' sessile, benthic community, apparently representing an autochthonous fauna that lived under clear, well-oxygenatod water, but which was killed off by the introduction of black mud. In other places a similar fauna is broken and disturbed and is clearly allochthonous, representing a transgressive marine phase overlying a coal.

The two overlying communities consist of a predominantly Dunbarella-conodont fauna with less common inarticulate brachiopods, cephalopods and typical fish, which is rngarded as an autochthonous, brackish or marine mobile epifaunal community, and the 'typical' Mecca fauna, which is dominated by vertebrates, containing up to 12 shark genera, as well as other groups. The only common invertebrate is a phyllocarid. This fauna is regarded, for reasons noted here, as an autochthonous thanatocoenose. Somewhat different burial communities are recognized in the Logan Quarry, but it is argued that the differences are the result of local samples of a single biotope, the overall aspects of the faunas being similar.

The annual burial rate of vortebrates at Mecca Quarry is estimated to be 475 individuals per $100 \mathrm{~m}^{2}$, a figure which is held to suggest a very high density of the living population. The vertical stratigraphic Mecca-Logan sequence is interpreted as a salt, brackish-fresh, salt cycle.

A final synthesis relates the detailed local physiographic régimes associated with the marine transgressions to their ecological effects. The pioneer community is dominated by fish in those cases where it is associated with incoming fresh water, and by Dunbarella where it is marine. Tho productid shell breccia is regarded, not as a pioneer community, but as a pre-transgression littoral and inlet community. The fossil distribution suggests that Dunbarella was stenohaline, incapable of salinity adjustments, whereas the other faunal elements, and the 'flotant' vegetation, were euryhaline. The Mecca site represented a deltaic coastal plain on the eastern shore of an epicontinental sea and the ecology of residual ponds and the freshwater environment (represented by the Garrard Quarry) is also reconstructed.

It may be argued that such a detailed and laborious study as this could have been more usefully applied over a wider area. For this is micropalæoecology, providing a limited number of carefully supported conclusions about a very restricted area, rather than grand but tenuous conclusions about Pennsylvanian environments across the face of the Earth. But in this very restriction lies its value, just as it was largely the fact that sixteenth- and seventrenth-century scholars became willing to forgo the joys of spoculation on ultimate causes and relationships for the disciplined, empirical study of local, restricted and carefully dofined problems, ovents and processes that led to the surge of scientific knowledge that marked that period of history.

The publication is well produced and illustrated with 56 plates and 51 text-figures. In an era of universal and inevitable editorial restriction of manuscript content it stands no less as an example of the value of unfettered monographic publication than it doos as a most notable contribution to palæoecology. F. H. T. RHodes

\section{THE FANNING ISLAND EXPEDITION, 1963}

$\mathrm{T}$ HE Fanning Island Expedition, consisting of four zoologists supported by the U.S. National Science Foundation and the Cocos Foundation, Inc., and sponsored by the University of Hawaii, carried out field studies and made collections of certain shoal water marine invertebrates on Fanning Island atoll, Line Islands, Pacific Oceania, during June 22-August 24. Fanning Island is situated in the equatorial current complex. These water masses could provide long-lived pelagic larvæ with the means of dispersal between the Indo-Pacific and the Atlantic-East Pacific faunal regions. The primary goal of the Expedition was to make collections of the sponges, corals, bivalved molluses and cirripeds for systematic treatment. It is hoped that this will provide fresh data for an analysis of the distribution of these groups in the eastern extremity of the Indo-Pacific region with special reference to the East Pacific Barrier.

Investigations by individual investigators on their special groups have provided information on several aspects of coral-reef biology which have hitherto received little attention. Studies on the Porifera included observations and experiments in the field on the effects of both grazing by fishes and of sedimentation on sponge survival. Data on stianding crop and gross productivity were recorded for two species.
Animals and algae associated with the stony corals were observed in an attempt to discover something of the natural history of the associations. Observations were made on the predation of corals by fishes and by invertebrates, the destructive action of surge on the outer reef, and sedimentation on the lagoon reefs. Sub-fossil corals were collected from large 'storm rocks' in which the coral colonies appeared to be oriented as they might have grown on the reef.

Studies of molluses included experiments in the field of the behavioural responses of the giant clam, Tridacna, to the presence of sediment and of fishes. The results were correlated with the anatomy of the nervous system. Observations were made of the anatomy of certain coralliophillid gastropods. A collection was made of sub-fossil shells from dry 'lakes'.

Collections were made of terrestrial, semi-terrestrial and marine crustaceans. Feeding mechanisms of certain cirripeds were observed under laboratory conditions. A hitherto unknown and complex feeding behaviour performed by a species associated with large decapod crustaceans was demonstrated and described.

Aside from special investigations and collections, the Expedition sought to record something of the biota and general physiographical features of the atoll so that it 